Patricia S. Pollard

Patricia S. Pollard is an economist at the Federal Reserve Bank

of St. Louis. Fichard D. Taylor provided research assistance.

\title{
Trade Between the United States and Eastern Europe
}

$T_{H}$ War II era, trade between th Eastern Europe was minuscule. The United States maintained high tariff barriers on imports from most Eastern European countries and also restricted its own exports to these countries. In particular, the United States prohibited the export to these countries of high-technology goods related to national security interests. Eastern Europe also maintained various trade restrictions on imports from the United States. Most Eastern European trade was controlled by the state and conducted within the Council for Mutual Economic Assistance (CMEA), the trade organization of the Soviet bloc countries.

With the disintegration of the Soviet system and the collapse of the CMEA trading bloc, Eastern European countries began to re-orient their trade to the West. As these countries undertook political and economic reforms, the United States reduced its tariff restrictions on their products. Consequently, trade between the United States and Eastern Europe has expanded substantially since 1988. This paper examines the growth and pattern of trade between the United
States and the three Eastem European countries which have made the greatest progress in adopting market reforms: the Czech and Slovak Federal Republic (CSFR), Hungary and Poland.

Studies have shown that the U.S. economy is likely to be one of the principal beneficiaries of economic liberalization in Eastern Europe. ${ }^{2}$ U.S. exports to, and investment in, the region should increase as the restructuring of the economies of Eastern Europe results in an increase in demand for capital goods and technology, and opens new markets for U.S. products. Such gains will be limited, however, if the Eastern European countries reverse the pattern of opening their markets and raise protectionist barriers against products from the United States.

Despite the initial steps taken to reduce trade barriers on Eastern European products, the United States maintains quantitative restrictions and other forms of protectionism on many products from Eastern Europe. Most significantly, the United States maintains a high degree of protection against the importation of textiles and apparel, chemicals, steel and agricultural products from Eastern Europe. These goods

${ }^{1}$ In January 1993, the Czech and Slovak Federal Republic split into two independent countries: the Czech Republic and the Sfovak Republic. With the exception of total export and import data, the data used in this paper end before the split occurred. 
Table 1

Growth in U.S. Trade 1988-93

\begin{tabular}{|c|c|c|c|c|c|c|}
\hline & \multicolumn{3}{|c|}{ US, imports (s millons) } & \multicolumn{3}{|c|}{ US exports (S millions) } \\
\hline & 1988 & 1993 & Growth & 1988 & 1993 & Growth \\
\hline 08182 & $\$ 876$ & $\$ 3415$ & $2899 \%$ & $\$ 551$ & $\$ 3001$ & $4422 \%$ \\
\hline Hurgary & 2939 & 4005 & 363 & 775 & 4339 & 459,7 \\
\hline Poland & 3756 & 1540 & 202 & 3037 & 9165 & 2018 \\
\hline $\begin{array}{l}\text { Combined CsFr, } \\
\text { Hungary, Poland }\end{array}$ & 7590 & 1,1960 & 576 & 436.3 & 1,6505 & 278.3 \\
\hline World & 4472824 & $580,054,4$ & 31.6 & 3227183 & 464,7672 & 440 \\
\hline
\end{tabular}

1 Based on rominal dollar values

2 The 1993 data for the CSFR were calculated by combining the data for the Czech Republic and the Sloval Republic. SOURCE. US Departireti of Commerce, Bureau of the Census

are produced by the sectors in which Eastern Europe is most competitive. The possibility exists for an increase in protectionism in Eastern Europe as these countries have become increasingly frustrated by the lack of progress in securing access to U.S. as well as other Western markets for their products. How the problems stemming from these trade barriers are handled will be an important determinant of future trade flows between the United States and the CSFR, Hungary and Poland.

This paper describes the recent changes in these trade flows and examines the restrictions facing Eastern Europe in its trade with the United States. The structure of the paper is as follows. Section two provides an overview of trade between the United States and the CSFR, Hungary, and Poland. The causes of the recent growth in trade between the United States and Eastern Europe are examined in section three. The product composition of this trade is discussed in section four. Section five examines U.S. restrictions on the products in which the CSFR, Hungary and Poland have their greatest comparative advantage. The conclusions are presented in section six.

\section{OVERVIEW OF TRADE}

Trade with the CSFR, Hungary and Poland has always comprised a low percentage of the total international trade of the United States. Neither U.S. exports to these countries nor imports from any of the three constitute more than 1 percent of total U.S. exports or imports. From the perspective of the CSFR, Hungary and Poland, however, trade with the United States constitutes a larger share of the international trade of each country. ${ }^{3}$

Despite its relatively small size, there has been a substantial expansion in trade between the United States and the CSFR, Hungary and Poland following the disintegration of the Soviet bloc. In dollar terms, U.S. imports from the three grew by 58 percent between 1988 and 1993 while U.S. exports to these three countries grew by 278 percent (see Table 1, and Figures 1 and 2). In comparison, total U.S. imports increased by 32 percent between 1988 and 1993 whereas total U.S, exports rose by 44 percent.

U.S. exports to the CSFR, Hungary and Poland have grown much faster than imports from these countries, Consequently, in 1988 the United

${ }^{3}$ The European Union (Belgium, Denmark, France, Germany, Greece, Ireland, Italy, Luxembourg, the Netherlands, Portugal, Spain and the United Kingdom) remains the major trading partner for these three Eastern European countries, accounting for more than half of their exports and imports.

${ }^{4}$ Exports from the United States to the three countries combined grew at a faster rate than exports from the European Union (208 percent compared to 180 percent) between 1988 and 1992 (the tatest year for which data for the European

Union were available). U.S. imports from the three Eastern European countries, however, grew more slowly than European Union imports over the same time period (27 percent compared to 133 percent). 
Figure 1

Total Annual U.S. Imports from Eastern Europe

Millions of dollars

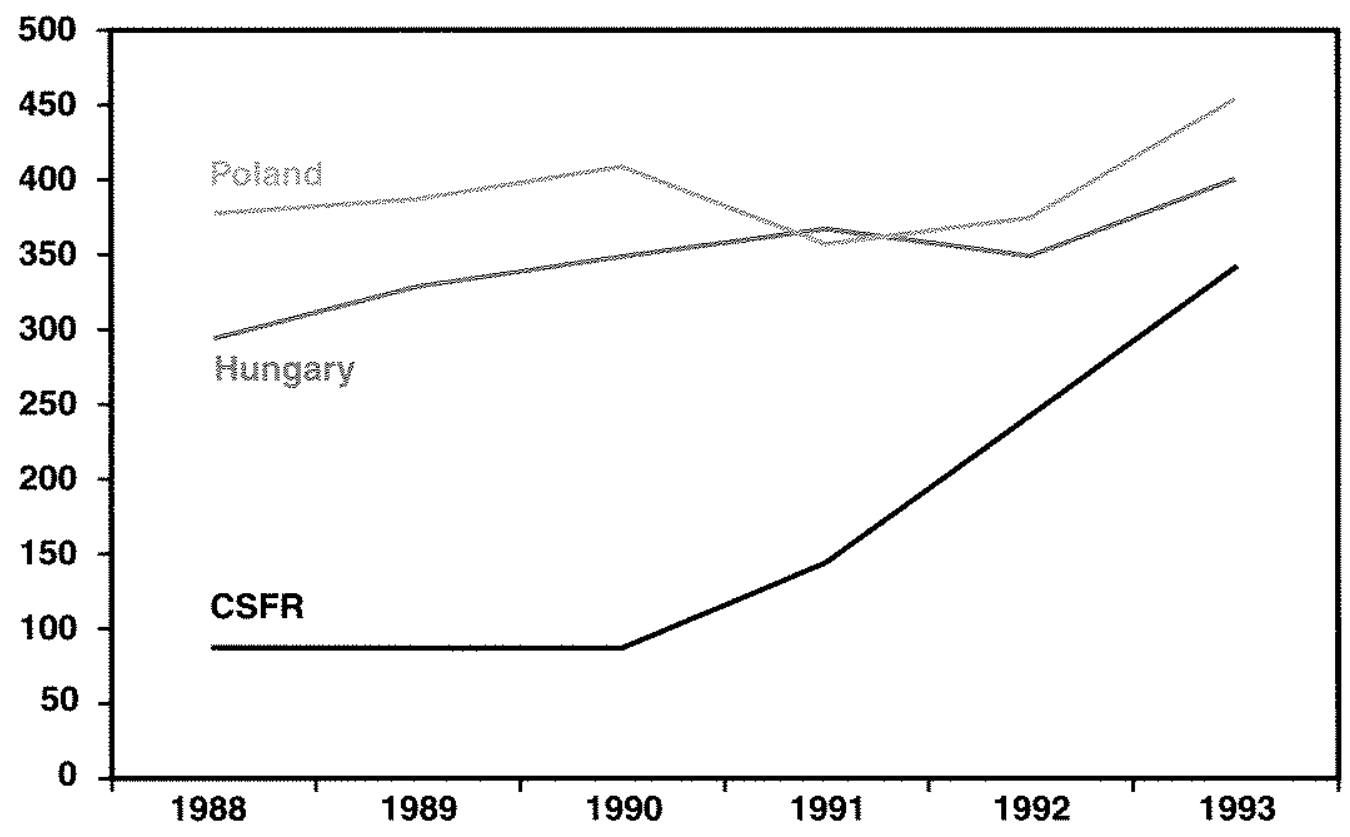

SOURCE: U.S. Department of Commerce, Bureau of the Census

Figure 2

Total Annual U.S. Exports to Eastern Europe

Millions of dollars

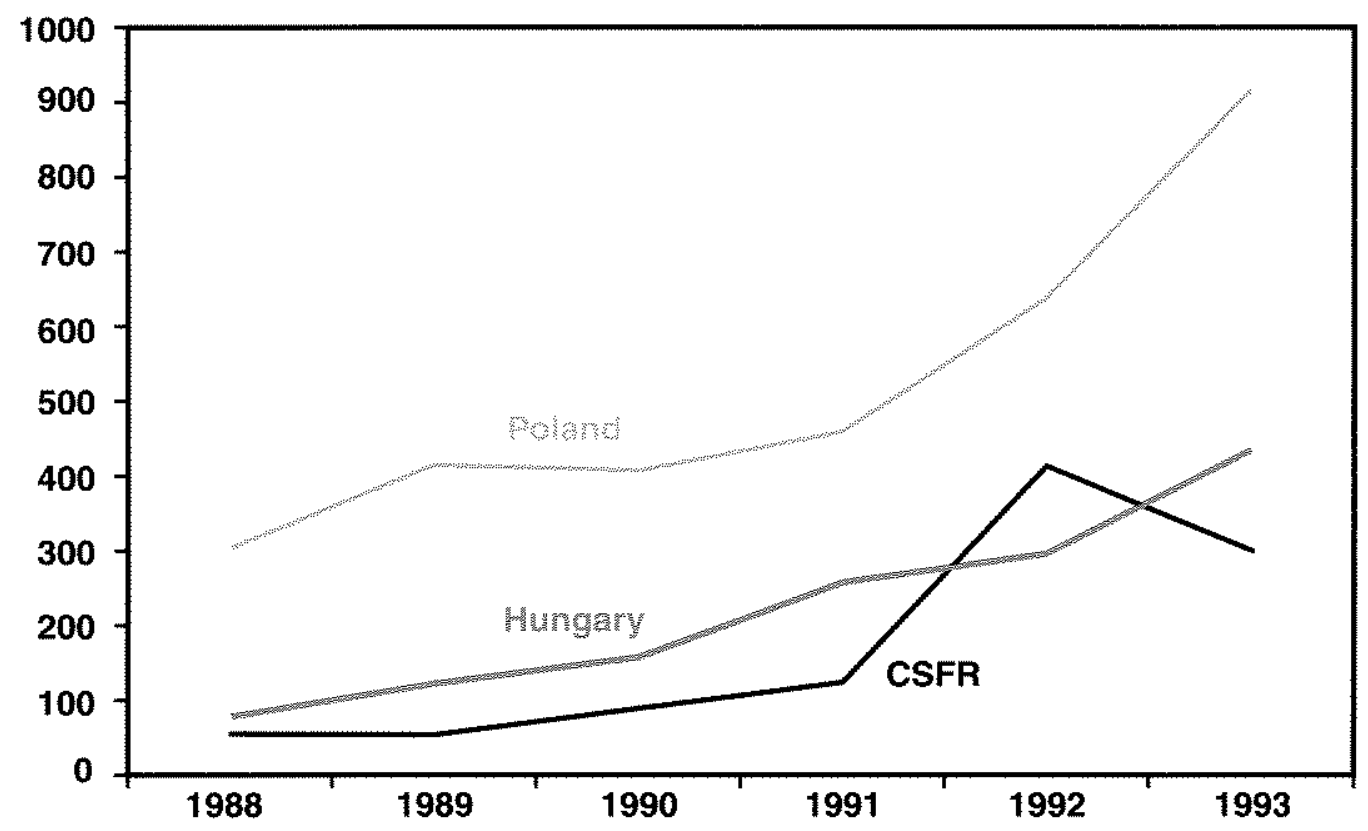

SOURCE: U.S. Department of Commerce, Bureau of the Census 


\section{The Jackson-Vanik Amendment to the Trade Act of 1974}

The Trade Expansion Act of 1951 suspended the most-favored-nation (MFN) status of any country deemed to be "under the control of the world Communist movement"' Between 1951 and 1974, the MFN status of Poland and Yugoslavia was restored. The U.S. Trade Act of 1974 reasserted the determination of the United States to withhold MPN status from Communist countries. Section 402 of the Trade Act states that MFN status could not be granted to any noninarket economy country which did not already have such statts. The Act established two exceptions, however. through which MFN status would be granted: 1) the President reported to Congress that the country did not restrict the enigration of its eitizens; and 2) the President waived compliance with the freedom of emigration require: ment. The Jackson-Vanik amendment established the freedom-of-emigration requirement. This requirement could only be waived if the President determined that doing so would "promote the objective of the amendment." MFN status still could not be granted until the United States had concluded a bilateral trade agreement with the country in question. Furthermore, as is standard, the granting of MFN status was to be done on a reciprocal. basis. Both the waiver of the lackson-Vanik amendment and the trade agreement had to be approved by a congressional resolution.
Waivers were granted for a one-year period, ending Jily 3 , but could be renewed each year by the President. Following the renewal of the waiver, Congress was given 30 days to pass a resolution eliminating the waiver.

Between 1974 and 1988, no country. was certified to have mot the Jackson-Vanik requirement. Under a waiver of this anendment, however, three countries were granted MFN status: Romania in 1975, Hungary in 1978, and China in 1980. In October 1989. Ilungary was accorded permanent MFN status following the passage of a freedom of-enigration law. The Czech and Slovak Federal Republic was granted waiver status in November 1990 , and permanent MFN status in October 1991 in accordance with the Jackson-Vanik amendment. Although such status was referred to as "permanent;" the Jackson-Vanik amendment required that the President report to Congress semiannually on a country's compliance wilh the emigration criteria. Gountries which were not subject to the Jackson Vanik requirements (such as Poland) had unconditional MFN status. In 1992, President Bush asked Congress to renove Hingary and the CSFR from the Jackson-Vanik restrictions, and these countries were granted unconditional MFN stalus.
United States Internationa/ Trade Commission

States ran a trade deficit with all three, but by 1993 the deficit had turned to a trade surplus with Hungary and Poland.

\section{CAUSES OF GROMTUYMU.S- USTIRN EUOPEAN TRADE}

The recent growth in U.S. trade with Eastern Europe is due in part to a general increase in trade between the former nonmarket economy countries and the West. The collapse of intra-
CMEA trade due to a movement to market pricing and the settlement of accounts in convertible currencies rather than the system of official exchange rates tied to the Soviet ruble, also played a part in re-orienting trade to the West. As these countries sought to modernize their production processes, they looked to the West as a source of capital and technology. Exports to the West provided a source of foreign currency with which to purchase these capital goods and were also a source of economic growth following 
the shrinkage of the domestic market resulting from the collapse of the old economic system. ${ }^{5}$

\section{REDUCTION IN U,S. TRADE BARELES HANG EASTERN EUROPE}

The growth in trade between the United States and the GSFR, Hungary and Poland also reflects the reduction of trade barriers by all parties. In the initial euphoria following the collapse of the Soviet bloc, the United States pledged to open its markets to Eastern European products in order to aid these countries in developing a market system. One of the first steps the United States took to encourage reform in Eastern Europe was to grant most-favored nation (MFN) status to these countries, leading to a substantial reduction in the tariff rates on imports from Eastern Europe. ${ }^{6}$ Poland was originally granted MFN status in 1960 , but this status was suspended in January 1981, following the imposition of martial law. It was not until November 1989 that Poland regained its MFN standing. Hungary was granted MFN status in 1978 under the waiver provision to the Jackson-Vanik Amendment to the 1974 Trade Act (see shaded insert on the opposite page for more on this amendment). The CSFR was the last of the three countries to gain MFN status, in November 1990. The importance of MFN status can be illustrated with reference to the textile and apparel industry. The MFN tariff rates on U.S. imports of textile and apparel range from 20 per. cent to 35 percent. In contrast, non-MFN tariff rates range from 50 percent to over 100 percent. $^{7}$

Additional changes in the U.S. treatment of imports from these countries have occurred as well. In November 1989, Hungary was designated as a "beneficiary developing country," making it eligible for tariff reductions granted under the generalized system of preferences (GSP). ${ }^{\tilde{}}$ In January 1990, Poland was deemed eligible for the GSP and in April 1991 the CSFR was deemed eligible. As part of the Trade Enhancement Initiative for Central and Eastern Europe (TEI) undertaken by the Bush administration in 1991, the United States expanded the list of products for which tariff reductions are granted to GSP countries to include products proposed by the CSFR, Hungary and Poland. The United States also concluded bilateral trade agreements with each country, increasing their import quotas on textiles and apparel. ${ }^{9}$

\section{REDUCTIONS IN EASTERN EUROPEAN TRADE BARRIERS FACING THE UNTTED STATES}

The Eastern European countries also sharply reduced their barriers to imports. In the CSFR, most quantitative restrictions on imports were eliminated or converted into tariffs. ${ }^{10}$ The average unweighted tariff rate was 5 percent until January 1992, when the CSFR requested and received GATT approval to raise its average tariff rate to 6 percent. ${ }^{+1}$ Hungary has an average unweighted tariff rate of 13 percent on imports in addition to a 2 percent customs clearance fee, while the average tariff on imports in Poland is 13.6 percent. Both countries have also eliminated most quantitative restrictions, although Hungary does maintain quotas on some consumer goods, while Poland limits imports of some alcoholic beverages. ${ }^{12}$ In comparison, the United States maintains a 6.8 percent average tariff rate on imports, while the tariff rate for the European Union and Japan is 6.5 percent. ${ }^{13}$ All of these entities also maintain nontariff barriers. Furthermore, the tariff rates in the CSFR, Hungary and Poland are lower than most countries at a comparable stage of development. ${ }^{14}$

\footnotetext{
${ }^{5}$ Although output data for the former nonmarket economies are not totally reliable, estimates by the International Monetary Fund (1993) indicate that between 1988 and 1992 , the economy of the CSFR shrank by 23 percent, the Hungarian economy shrank by 21 percent, and the Polish economy shrank by 16 percent.

${ }^{6}$ MFN status guarantees that the tariffs imposed on a country's products will be no higher than those imposed on the imports of any other country. MFN tariff rates have been reduced substantially through successive trade rounds held under the General Agreement on Tariffs and Trade (GATT). For the period covered in this paper, the average MFN tariff rate on manufactured goods imported into the United States was 4 percent. In contrast, non-MFN tariff rates are set by the Smoot-Hawley Tariff Act of 1930.

${ }^{7}$ Erzan and Holmes (1992, p. 4).
}

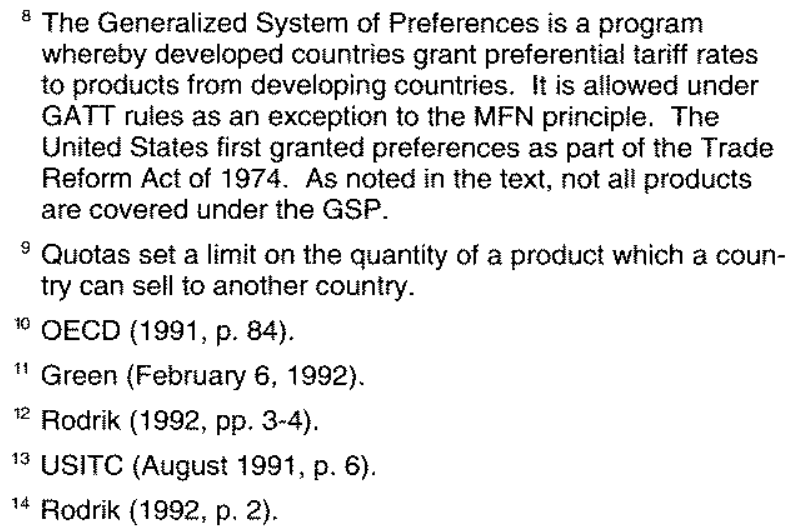

${ }^{8}$ The Generalized System of Preferences is a program whereby developed countries grant preferential tariff rates to products from developing countries. It is allowed under GATT rules as an exception to the MFN principle. The United States first granted preferences as part of the Trade Reform Act of 1974. As noted in the text, not all products are covered under the GSP.

${ }^{9}$ Quotas set a limit on the quantity of a product which a country can sell to another country.

${ }^{10}$ OECD $(1991$, p. 84).

"Green (February 6, 1992).

12 Rodrik (1992, pp. 3-4).

${ }^{13}$ USITC (August 1991, p. 6).

${ }^{14}$ Rodrik (1992, p. 2). 
Tariff rates in the CSFR, Hungary and Poland also tend to be lowest on capital goods and raw materials, the major U.S. export products to these countries. In contrast, as discussed below, trade restrictions in the United States are highest on the goods for which the three Eastern European countries have a comparative advantage.

\section{PEODUCT COMTOSTION OF TRATE}

More than half of all U.S. merchandise exports to the CSFR and Hungary, and slightly less than one-half of U.S. exports to Poland, are capital goods (Table 2). Although capital goods were one of the largest categories of U.S. exports to the CSFR, Hungary and Poland in both 1988 and 1992 , there was a clear shift during this period from industrial supplies and materials to capital goods. Put simply, there was an increase in the demand for capital due to industrial restructuring.

Another factor contributing to the shift toward imports of capital goods is the easing of the Coordinating Committee on Multilateral Export Controls (COCOM) restrictions. COCOM was created in 1949 to control the exportation to the Soviet bloc countries of products and technology which could be used for military purposes. ${ }^{15}$ The importance of the relaxation of COCOM restrictions is highlighted by the growth in U.S. exports of computers, semiconductors and telecommunications equipment-high-technology industries, relying heavily on research and development conducted by highly skilled workers. Such exports grew from 4.9 percent to 20.3 percent of total exports to the CSFR, from 4.4 percent to 12.4 percent for Hungary, and from 1.0 percent to 10.9 percent of total U.S. exports to Poland.

In contrast, the CSFR, Hungary and Poland are countries whose productive resources are characterized by relatively large amounts of semiskilled labor, and all suffer from a lack of up-to-date capital. These factors, in combination with their relatively low-wage rates, point to production cost advantages in products requiring large amounts of semiskilled labor. The product composition of U.S. imports from the CSFR, Hungary and Poland does fit this pattern (Table 3). In 1992, consumer goods, particularly apparel
Table 2

Major Product Composition of U.S. Exports, by End-Use Category (percent of total)

\begin{tabular}{|c|c|c|c|c|c|c|}
\hline & \multicolumn{2}{|c|}{$\operatorname{csp} n$} & \multicolumn{2}{|c|}{ Hungary } & \multicolumn{2}{|c|}{ Poland } \\
\hline & 1988 & 1992 & 1988 & 1992 & 1988 & 1992 \\
\hline Food \& beverages & 98 & 39 & 07 & 21 & 881 & 15,4 \\
\hline Indestrial supplies & 442 & 43 & 378 & 89 & 24.3 & 79 \\
\hline Capial goods & 462 & 738 & 40.3 & 615 & 152 & 458 \\
\hline Attonolive & 0 & 27 & 111.4 & 70 & 13 & 27 \\
\hline Consuner goods & 58 & 120 & 79 & 170 & 78 & 13.0 \\
\hline Exports, h.e.c. & 31 & 33 & 1.9 & 3.4 & 134 & 152 \\
\hline
\end{tabular}

and footwear, accounted for the largest category of U.S. imports from each country.

The CSFR and Poland have increased their exports of capital goods to the United States, although these goods are not high-technology products. For the CSFR and Poland, nearly all capital goods exported to the United States are nonelectrical machinery and parts. Within this group, industrial and agricultural machinery, and machine tools are the most important.

A more formal way to analyze the exports of a country is to calculate an index of relative comparative advantage (RCA). This index is calculated as follows:

(1) $R C A^{n}=\frac{X_{i j}^{n}}{X_{i j}} \div \frac{X_{-i j}^{\pi}}{X_{-i j}}$

where $X^{n}$ are exports of commodity $n ; i$ is the country of origin; $j$ is the country of destination; and $-i$ is the rest of the world (all countries excluding country $i$ ). Equation 1 indicates that the relative comparative advantage of country $i$ in any good $n$ depends on the share of that good in country i's exports to country $j$ relative to the share of good $n$ in the rest of the world's exports to country $j$. In general, if this ratio is greater than 1 , then country $i$ has a comparative advantage in producing that product relative to the rest of the world. ${ }^{16}$
${ }^{15}$ COCOM was disbanded on April 1, 1994. The members of COCOM were Australia, Belgium, Canada, Denmark, France, Germany, Greece, Italy, Japan, Luxembourg, the Netherlands, Norway, Portugal, Spain, Turkey, the United Kingdom and the United States.

\footnotetext{
${ }^{16}$ For more details on this index and iss use in determining the comparative advantages of Eastern European countries, see Murrell (1990) and USITC (1991).
} 
Table 3

\section{Major Product Composition of U.S. Imports (percent of total)}

\begin{tabular}{|c|c|c|c|c|c|c|}
\hline & \multicolumn{2}{|c|}{ Csfr } & \multicolumn{2}{|c|}{ Hungary } & \multicolumn{2}{|c|}{ Poland } \\
\hline & 1988 & 1992 & 1088 & 1992 & 1988 & 1992 \\
\hline food \& boverages & 56 & 4.1 & 206 & 170 & 359 & 150 \\
\hline Industral supplies & 21.6 & 23.2 & 204 & 172 & 269 & 293 \\
\hline Capial goods & 166 & 22.2 & 63 & 135 & 105 & 183 \\
\hline Aulomotive & 5.0 & 38 & 139 & 145 & 08 & 14 \\
\hline Consumer goods & 493 & 431 & 38.2 & 86.8 & 247 & 339 \\
\hline Exports,, $\mathrm{ccc}$ & 20 & 86 & 08 & 10 & 12 & 2.2 \\
\hline
\end{tabular}

For example, in 1992 the CSFR exported $\$ 242$ million of merchandise to the United States, with shipments of footwear accounting for $\$ 14$ million of this total. In contrast, world merchandise exports to the United States totalled $\$ 532$ billion in 1992, and footwear exports accounted for $\$ 7$ billion of this total. Thus, whereas footwear comprised nearly 6 percent of the merchandise exports of the Czech and Slovak Federal Republic to the United States, it accounted for slightly more than 1 percent of world exports to the United States. Since the share of footwear in the CSFR's exports to the United States was larger than the share of footwear in world exports to the United States, the CSFR is said to have a relative comparative advantage in this product (RCA footwear $>1$ ). ${ }^{17}$ If the share of footwear in the CSFR's exports to the United States had been smaller than the share of footwear in world exports to the United States, the CSFR would have a relative comparative disadvantage in this product $\left(\mathrm{RCA}^{\text {footwear }}<1\right)$.

Using the index of relative comparative advantage, it is possible to determine in which product categories each of the three Eastern European countries has the greatest relative comparative advantage, and also to look at changes in each country's comparative advantage as each has initiated the transition to a market economy. ${ }^{18}$

Table 4 shows the relative comparative advantage indexes for each of the three Eastern European countries, by principal end-use category of exports in 1988 and 1992, based on U.S. Bureau of the Census data. Appendix tables provide the RCAs for each country using five-digit, end-use categories in each year from 1988 to 1992.

\section{CULAGES WN WITHVE CONPARATIVE ATVANTAGZ}

Two major developments occurred between 1988 and 1992 that may have affected the relative comparative advantages of the Eastern European countries. The first was the progress made in moving from a command system of production to a marketmoriented one. Producer and consumer prices were decontrolled, government subsidies to industry were reduced or in many cases eliminated, and privatization programs were implemented. These measures should eventually result in more efficient production leading to an index of comparative advantage more directly related to market forces.

The second development was the easing of trade restrictions by the United States. As noted above, only Hungary enjoyed MFN status in its trade with the United States in 1988, and none of the three countries was considered eligible for GSP status. ${ }^{\prime 9}$ By 1992, all three had both MFN and GSP status, as well as increased quotas for textiles and apparel. The relaxation of these restrictions should allow the computed relative comparative advantage to more accurately reflect the true comparative advantage of each country.

Despite these two developments, the evidence presented in Table 4 and the Appendix does not

(1990) and Collins and Rodrik (1991) to calculate the comparative advantages of the Eastern European countries in trade with the West prior to economic liberalization. Both of these studies calculate the index of comparative advantage only for major product categories, but their results are similar to the results based on 1988 data used in this paper.

10 The United States did not extend GSP benefits to the Soviet bloc countries.

$$
\frac{X_{i}^{*}-M_{i}^{n}}{X_{i}^{n}+M_{i}^{n}}
$$

the difference between country i's exports of good $n$ and its impors of good $n$ divided by the sum of country is exports and imports of good $n$. This index was used by Fieleke 
Table 4

Relative Comparative Advantage Indexes: By Principal End-Use Category

\begin{tabular}{|c|c|c|c|c|c|c|c|}
\hline & \multirow[b]{2}{*}{ Category } & \multicolumn{2}{|c|}{ CSFR } & \multicolumn{2}{|c|}{ Hungary } & \multicolumn{2}{|c|}{ Poland } \\
\hline & & 1980 & 1992 & 1980 & 1992 & 1989 & 1992 \\
\hline Foods, feeds \& beverages & 0 & 100 & 0.78 & 3.64 & 326 & 6.41 & 2.87 \\
\hline Agrcultura) & 00 & 141 & 1.07 & 5,14 & 4.51 & 8.44 & 349 \\
\hline Nonagricultural & 01 & 005 & 005 & 0.18 & 010 & 1.70 & 128 \\
\hline Industrial supplies $\&$ materlals & 1 & 081 & 080 & 076 & 0.66 & 101 & 113 \\
\hline Energy products & 10 & 000 & 000 & 0.02 & 0.02 & 0.00 & 0.04 \\
\hline Paper \& paper producls? & 11 & 0.04 & 001 & 1001. & 0.00 & 000 & 000 \\
\hline Textile supplies \& refaled nuateriats & 120008121 & 4.81 & 745 & 5.46 & 155 & 374 & 482 \\
\hline Ghemicals, excuding nedicinals & 125 & 0.40 & 127 & 0.97 & 1,16 & 0.63 & (31) \\
\hline Bulding materials, except netals & 13 & 0.52 & 0.20 & 0.02 & 000 & 008 & 0.39 \\
\hline Metals & 16 & $2 \longdiv { 1 9 }$ & 073 & 064 & 0.39 & 1899 & 075 \\
\hline Metalloproducts & 15 & 9801 & 0.80 & 250 & 407 & 254 & 975 \\
\hline Nonnelalic ninerals \& nonmetallic prods. & 16 & 073 & 0.48 & 058 & 107 & 0.23 & 0.14 \\
\hline Capital goods except autongive & 2 & 072 & 0.88 & 0.27 & 0.54 & 0.46 & 072 \\
\hline Electic generating meehner, elodil & & & & & & & \\
\hline apparaus 8 parts & 20 & 0.31 & 0.07 & 0.31 & 1229 & 0.12 & 079 \\
\hline Nonelectric nel parts \& atfacknents. & 21 & 093 & 111 & 0.30 & 0.50 & 046 & 074 \\
\hline Transpertation equijmen, exeepl aito & 22 & 000 & 006 & 001 & 005 & 0.68 & 0.51 \\
\hline Autonotive vehioles, parts \& engines & 3 & 025 & 022 & 070 & 0.84 & 004 & 0.08 \\
\hline Consumer goods (nontood), except auto. & 4 & 2,25 & 1867 & 175 & 1160 & 113 & 146 \\
\hline Consumer rondurables, manufactured & 40 & 2.66 & 184 & 2,72 & 2.29 & $\mathbf{1} 49$ & 162 \\
\hline Consumer durables, hanuraclured & 41 & 159 & 1.44 & 1.08 & 106 & 092 & 146 \\
\hline Unmanufaclured consumer goods & 42 & 4.68 & 6.17 & 001 & 0.02 & 0.12 & 008 \\
\hline Exports not elsewhere counted & 50. & 0.68 & 109 & 026 & 031 & 043 & 0.65 \\
\hline
\end{tabular}

show major shifts in relative comparative advantage between 1988 and 1992. In general, the product categories in which a country exhibited a relative comparative advantage ( $\mathrm{RCA}>1)$ in 1988 are the same as those in 1992 , and vice versa. ${ }^{20}$ Furthermore, Hungary, which had made the most progress toward reforming its economy at the start of 1988 and faced the lowest tariffs on its exports to the United States of the three countries, had no fewer shifts in its relative comparative advantage (movements from $\mathrm{RCA}>1$ to $\mathrm{RCA}<1$, and vice versa) between 1988 and 1992 than the CSFR or Poland.
The lack of major shifts in relative comparative advantage is not surprising given the years needed to restructure the production of the formerly command-based economies. Such restructuring could change the pattern of comparative advantage of the Eastern European countries. There is some evidence, however, that the estimates given in this paper may be close to reflecting the comparative advantage of each country which will prevail after the transition to a market-based system is completed within the CSFR, Hungary and Poland. The product composition of each country's trade with the West was different from

\footnotetext{
${ }^{20}$ Another method to determine changes in relative comparative advantage is to compute a rank correlation coefficient for each country. A rank correation coefficient of 1 indicates no change in the ordering of industries by the RCA index between 1988 and 1992 , zero indicates no relationship between the 1988 ordering and the 1992 ordering, and
}

-1 indicates a complete reversal in the ordering. The rank correlation coefficients are .74 for the CSFR, 77 for Hungary, and .63 for Poland, using the five-digit product categories. 
its trade with the other CMEA members. As noted by Collins and Rodrik (1991), Eastern Europe's trade with the West was less distorted than its intra-CMEA trade and, thus, more likely to be reflective of its comparative advantage. ${ }^{21}$ With respect to intra-CMEA trade, the products traded and their prices were set through bilateral government agreements. ${ }^{22}$ In contrast, products exported to Western countries and the prices of these products were subject to international competition. An OECD study of Hungary found that even prior to 1989 , Hungary based its trade with the West on its comparative advantage, ${ }^{23}$ There is little evidence that the CSFR, Hungary or Poland have redirected their intra ${ }^{-C M E A}$ sales to the West. ${ }^{24}$

\section{Relative Comparative Advontage in 1992}

The one-digit, end-use categories show that the CSFR, Hungary and Poland exhibited a relative comparative advantage in consumer goods in 1992. The latter two countries also had a comparative advantage in foods, feeds and beverages.

On a more disaggregated basis, all three countries in 1992 exhibited a relative comparative advantage in agricultural goods, textile supplies \& related materials, chemicals (excluding medicinals), and manufactured consumer goods.

Among consumer goods, all three countries had a relative comparative advantage in some type of textile apparel \& household goods made from textiles, and footwear. ${ }^{25}$ In addition, Hungary and Poland had a relative comparative advantage in metallic products.

In summary, these three Eastern European countries exhibit a relative comparative advantage in agricultural products, chemicals, textiles, apparel and footwear, with the exception of the CSFR in metallic products. ${ }^{26}$ This pattern of comparative advantage fits the typical pattern for developing countries. ${ }^{27}$
If these sectors do indeed represent the comparative advantage of the CSFR. Hungary and Poland, one would expect to see further increases in the export to the United States of these products. Furthermore, as these countries become more adept at marketing and supplying goods for export, trade in these products should increase.

In actuality, however, the potential for increased exports to the United States of the products in which the three have a comparative advantage is limited by the fact that these goods fall into the "sensitive sectors" categorization. These are products typically produced by sectors in decline and are highly protected from international competition.

\section{U.S. TRADE RESRTCTONS ON WASTERY EUROPEAN PRODUCTS}

The initial emphasis in the United States on opening its markets to Eastern European products has given way to protectionist sentiments as the CSFR, Hungary and Poland have shown that they can compete successfully with certain Western industries and, as a consequence, imports to the United States from these countries have expanded. As noted above, many sectors in which Eastern Europe is most competitive are highly protected in the United States. For example, the textile, apparel and footwear industries enjoy the highest level of tariff protection of all U.S. manufacturing industries. Tariff rates for textiles and apparel average 18 percent ad valorem, while tariffs on certain footwear products range as high as 40 percent. ${ }^{28}$ The U.S. dairy industry also enjoys a high level of tariff protection, with rates ranging from 10 percent to 25 percent. $^{29}$ Furthermore, none of these products are eligible for GSP tariff reductions.

In addition to the tariff barriers facing Eastern Europe on the products in which it has a comparative advantage, most of these products are subject to nontariff barriers. For example, the

\footnotetext{
${ }^{21}$ Collins and Rodrik (1991, p. 50).

22 OECD (1992, p. 83).

${ }^{23}$ OECD (1993, p. 91).

${ }^{24}$ See, for example, Rodrik (1992, p. 18) and OECD (1993, pp. 91-3).

${ }^{25}$ See the Appendix for details.

${ }^{26}$ These findings are supported by changes in prices relative to the overall producer price indexes in Hungary and Poland between 1989 and 1991. In conjunction with the liberalization of prices, reductions in subsidies, and the progress made in making their currencies convertible, Hungary and Poland both experienced a decline in the prices of textiles,
}

clothing, leather and metal products relative to their producer price indexes. Hungary also saw a drop in the relative price of food, while Poland experienced a fall in the relative price of chemicals. The decline in the relative prices of these products was due primarily to the avallablity of tower cost inputs and an increase in production efficiency. See the Organization for Economic Co-operation and Development (1993) for the defails of the relative price changes.

${ }_{27}$ Bank for international Settements (1993, p.70) and Collins (1991, p. 223).

${ }^{28}$ For a further discussion of U.S. tariff protection, see Finger (1992) and Ray (1991).

${ }^{29}$ U.S. Harmonized Tariff Schedule 1993. 
United States maintains quotas on textiles, apparel and some agricultural products, most notably dairy products, a category in which the CSFR, Hungary and Poland have a relative comparative advantage. In addition, quotas on steel exports to the United States from these countries, as well as from many others, were in place during most of the period covered in this paper.

Although many of the quotas which apply to the CSFR, Hungary and Poland remain underutilized, they still may act as an effective restraint on trade. Quotas are not applied by major product category but to specific products. Thus, rather than setting a limit on the importation of wool clothing, the United States places limits on specific types of wool clothing-for example, men's and boy's wool suit-coats. The quota limit on a specific product may be so low that it is not profitable to export such a small quantity. Furthermore, the quota agreement may require that exports be spread out over each year, further limiting the profitability of trade. For example, the agreement limiting the export of Polish steel to the United States prohibited Poland from exporting more than 60 percent of its yearly quota allotment in any two consecutive quarters. ${ }^{30}$ The 1992 textile agreement between the United States and the GSFR requires the latter to space its exports to the United States "within each category evenly throughout each agreement period."

The United States has restricted the flow of certain goods simply by threatening to place limits on their importation. For example, the most recent textile agreement between the United States and Poland lists products for which no quotas are set, but for which the United States reserves the right to "consult" with the government of Poland to restrain the trade of these products if the United States believes such products are causing "market disruption" or the "risk of market disruption." The agreement even sets limits on imports of these products while consultations are in progress. ${ }^{32}$ Another method

${ }^{30}$ USITC (March 1990, p. 11+8).

${ }^{31}$ United States Department of State (July 21, 1992, p. 4).

${ }^{32}$ See U.S. Department of State (January 28,1992 , pp. 8-10)

${ }^{33}$ Dumping is the practice of selling a product in foreign markets at a lower price than in the home market, or at price below the cost of production. For an analysis of the use of anti-dumping regulations as a protectionist device, see Coughtin (1991).

${ }^{34}$ The United States is not alone in restricting access to products from Eastern Europe. The European Union, despite concluding association agreements with the CSFR, Hungary used to restrict exports of sensitive products to the United States is anti-dumping regulations. ${ }^{33}$

Tariff barriers, nontariff barriers and anti-dumping measures have all been used to restrict the flow of goods from the CSFR, Hungary and Poland to the United States. Although some relief has been granted to Eastern Europe in recent years, restrictions still prevail on the products in which these countries have a relative comparative advantage ${ }^{34}$ The importance of these restrictions for each sector are discussed below.

\section{Sted}

The granting of MFN status to the CSFR and Poland reduced the tariffs they faced on steel exports to the United States from an average of 20-25 percent to an average of less than 5 percent. ${ }^{35}$ However, quota restrictions and anti-dumping measures act as limits on steel products. Until March 1992, steel from the CSFR, Hungary and Poland was subject to quantitative restrictions. These limits were raised in 1989 and 1991, and, as part of the Trade Enhancement Initiative for Central and Eastern Europe, the United States committed itself to adjusting the ceilings further, either through increased flexibility in the administration of the quotas, or increasing the actual quotas ${ }^{36}$ This commitment, however, was never acted upon. At the end of March 1992, the United States allowed all of the quantitative restrictions on steel to elapse.

The end of quantitative restrictions on U.S. steel imports did not open the U.S. market to steel products from Eastern Europe. Within two months of the elimination of quotas, the U.S. steel industry accused every significant foreign supplier of steel to the United States of dumping their product in the U.S. market. In the summer of 1993, the USITC ruled that steel producers in 19 countries had dumped their products in the U.S. market, and that this action had resulted in injury or the potential for injury to the U.S. steel industry. In accordance with this finding, the

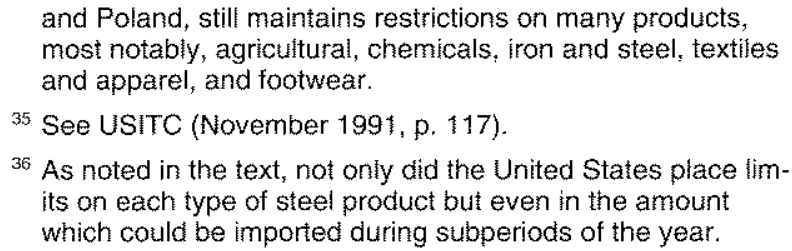
most notably, agricultural, chemicals, iron and steel, textiles and apparel, and footwear.

${ }^{35}$ See USITC (November 1991, p, 117).

${ }^{36}$ As noted in the text, not only did the United States place limits on each type of steel product but even in the amount which could be imported during subperiods of the year. 
USITC imposed duties ranging from 18 percent to 109 percent of the value of the steel product on imports from the dumping countries. Dumping duties on Polish exports to the United States of carbon steel plate were levied at 62 percent, effectively eliminating Polish exports of this product to the U.S. market. Although no charges of dumping were filed against the CSFR and Hungary, the size and extent of the dumping duties is likely to limit the growth of steel exports to the United States from all countries. ${ }^{37}$

Prior to the anti-dumping case, the CSFR, Hungary and Poland had begun programs to make their "steel enterprises more market-oriented, costconscious and perhaps more export oriented." ${ }^{38}$ Use of anti-dumping measures by the United States is an indication to these countries that even if they follow the prescriptions of the West and develop an efficient industry, they still may be denied access to U.S. markets.

\section{Texiles and Apporel}

U.S. imports of textiles and apparel from the CSFR, Hungary and Poland are covered by quotas in accordance with the Multifiber Arrangement. ${ }^{39}$ Before the granting of MFN status to the CSFR and Poland, quota utilization rates (which indicate how close a country comes to meeting the quota on a particular product) for these countries were very low, because the tariffs acted as an effective barrier to trade. ${ }^{40}$ Even though MFN tariffs are high, utilization rates have increased since the granting of MFN status. Utilization rates rose even as the United States has negotiated new textile and apparel agreements with the CSFR, Hungary and Poland which have increased these quotas.

Under the Trade Enhancement Initiative for Central and Eastern Europe, the United States pledged to take steps to increase its imports of textiles and apparel from Eastern Europe. In accordance with this initiative, the United States raised the quotas on some imports from the CSFR, Hungary and Poland. The United States also promised to consider setting quotas for more broadly defined product categories which would allow the countries more flexibility in meeting the quotas. ${ }^{43}$

\section{Chemicals}

Tariffs on industrial chemicals and fertilizers average only 2 percent ad valorem and, thus, since the granting of MFN privileges to all three countries, they do not represent a significant barrier to trade. According to the Organization for Economic Comoperation and Development (OECD), the main obstacle to the growth of Eastern European chemical exports has been the use of anti-dumping measures by the West. ${ }^{42}$ For example, the U.S. chemical industry filed dumping charges in 1992 against the imports of sulfanilic acid from Hungary. ${ }^{43}$ The USITC found preliminary evidence that the Hungarian producers were dumping this product in the United States and causing harm to the U.S. chemical industry. Temporary duties equal to 58 percent of the value of Hungarian shipments of sulfanilic acid were assessed. These duties were rescinded when, in its final decision in February 1993, the USITC ruled that there was not sufficient evidence that these imports were injuring the domestic industry.

\section{Agriculture}

Agricultural exports from the CSFR, Hungary and Poland are affected both by U.S. agricultural subsidies and nontariff barriers. According to the USITC, the only nontariff barriers in agriculture that significantly affect the CSFR, Hungary and

\footnotetext{
${ }^{37}$ The imposition of duties which block certain producers from the U.S. market does not necessarily lead to an increase in imports from the "nondumping" producers. The U.S. industry is free to file charges of dumping against foreign competitors at any time. Thus, the finding of dumping may act as a deterrent to other producers to expand their exports to the United States.

38 USITC (November 1991, p. 117).

39. The Multifiber Arrangement (MFA) refers to the bilaterally negotiated quota restrictions on textiles and apparel, which are placed by developed countries on imports from developing countries. The MFA is negotiated under the auspices of the GATT committee on textiles. See Hamilton (1990).

If Congress approves the GATT Uruguay Round of muitilatera trade agreements, the MFA will be phased out over a
} 
Poland are the quantitative restrictions on cheese imports. ${ }^{44}$ Most cheese products are covered by quotas and those which are not face high tariff barriers. Furthermore, as noted above, cheese products are not eligible for GSP treatment.

As part of the TEI, the United States committed itself to increasing the access of cheese products from these countries into the U.S. market. Nonetheless, no progress has been made on this proposal. For example, in 1991 Hungary petitioned the United States to allow GSP benefits for the importation of goya cheese, one of the few cheeses for which importation into the United States is not limited by quotas. Imports, however, are restricted by a 25 percent tariff. Hungary provided 25 percent of the total U.S. imports of goya cheese in 1990. Although no goya cheese is produced in the United States, the U.S. dairy industry opposed the extension of GSP benefits to goya cheese, arguing that this product was a substitute for domestically produced, hard, Italian-type cheeses. ${ }^{45}$ Because of this opposition, the United States refused Hungary's request to add goya cheese to the list of GSP-eligible products.

\section{CONCUSTON}

Foreign trade is vitally important for the CSFR, Hungary and Poland to facilitate the re-structuring of their economies. These countries are dependent upon exports to ensure a supply of foreign currency to finance capital purchases (reducing the pressures to incur foreign debt), and to promote economic growth, which in turn is critical to their political stability.

The governments of the CSFR, Hungary and Poland have made great progress over the past few years in reforming their economies. The role of the state has been reduced substantially through the deregulation of prices, the privatization of industries, and the adoption of legislation aimed at fostering the market system. Furthermore, all of these countries have substantially liberalized their trading environments by eliminating quotas, harmonizing tariffs, and permitting the convertm ibility of their currencies. Officials in these countries cite the continuation of Western trade barriers as one of the primary hindrances to their successful transition to market democracies. ${ }^{45}$
The United States' economic growth has benefitted from the reforms undertaken by the Eastern European countries. Most notably, U.S. exports to these countries have expanded substantially. Despite these gains, the United States continues to restrict access to its markets to goods produced in Eastern Europe. As shown in this article, the products in which the CSFR, Hungary and Poland have the greatest comparative advantage are precisely those in which the United States maintains the greatest restrictions on trade. Reducing the trade barriers to these products will spur economic growth in Eastern Europe, and is an important step the West can take to ensure that the countries of Eastern Europe continue along the path of reform.

\section{REFERENCS}

Bank for International Settlements. 63rd Annual Report, June 1993.

Burke, Justin. "Central European Countries Cite Obstacles to Economic Integration," The Christian Science Monitor, January 19,1994 , p. 9.

Collins, Susan $M_{\text {, }}$ and Dani Rodrik. Eastem Europe and the Sovief Union in the World Economy. Institute for International Economics, May 1991.

Collins, Susan M. "Policy Watch: U.S. Economic Policy Toward the Soviet Union and Eastem Europe," The Joumal of Economic Perspectives (fall 1991), pp. 219-27.

Coughin, Cletus C. "U.S. Trade-Remedy Laws: Do They Facitiate or Hinder Free Trade?" this Review (July/August 1991), pp. 3-18.

Erzan, Refik, and Cnristopher Holmes. "The Restrictiveness of the Mutti-Fibre Arrangement on Eastem European Trade," Policy Research Working Papers, WPS 860, The World Bank (February 1992).

Fieleke, Norman S. "Commerce With the Newly Liberalizing Countries: Promised Land, Quicksand, or What?" New England Economic Review (May/June 1990), pp. 19-33.

Finger, Michael J. "Trade Policies in the United States," National Trade Policies, Handbook of Comparative Economic Policies, vol. 2. Greenwood Press, 1992, pp. $79-108$.

Green, Paula L. "U.S. Monitors EC Tes With Eastern Europe," Journal of Commerce (February 6, 1992).

Hamilton, Carl B., editor. Textiles Trade and the Developing Countries: Eliminating the Multi-Fibre Arrangement in the 1990s. The Worid Bank, 1990.

International Monetary Fund. World Economic Outlook (May 1993).

Murrell, Peter. The Nature of Socialist Economies: Lessons from Eastern European Foreign Trade. Princeton University Press (1990).

\footnotetext{
4 USITC (April 1992, p. 18).

${ }^{45}$ See USITC (March 1992) for details.

${ }^{46}$ Burke (January 19, 1994).
} 
Organization for Economic Co-operation and Development. Economic Surveys: Czech and Slovak Federal Republic. OECD, December 1991.

Reforming the Economies of Central and Eastern Europe. OECD, 1992.

Economic Surveys: Hungary. OECD, 1993.

Ray, Edward J. "Protection of Manufacturers in the United States," in David Greenaway and others, eds., Global Protectionism. St. Martin's Press, 1991, pp. 12-39.

Rodrik, Dani. "Foreign Trade in Eastern Europe's Transition: Early Results," National Bureau of Economic Research Working Paper Series No. 4064 (May 1992).

U.S. Department of State, Bureau of Economic and Business Affairs, Textiles Division. "United States and the Republic of Poland Sign New Texille Agreement" (Textiles Division, Public Release, January 28, 1992).

"United States and the Crech and Slovak Federal Republic Amend Their Bilateral Textile Agreement" (Textiles Division, Public Release, July 21, 1992).

United States International Trade Commission. U.S. Laws and U.S. and EC Trade Agreements Relating to Nonmarket Economies. USITC, March 1990.

United States International Trade Commission, Office of Economics. "Legisfation to Ensure Role for Congress in
Extending MFN Status to Nonmarket Economy Countries," International Economic Review (June-July 1990),

pp. 7-8.

"Liberalization of Foreign Trade in Czechoslovakia, Hungary, and Poland: Progress and Prospects," Intemational Economic Review (August 1991), pp. 547.

United States International Trade Commission. Central and Eastern Europe: Export Competitiveness of Major Manufacturing and Services Sectors. USITC Publication 2446 (November 1991).

President's List of Articles Which May Be Designated Or Modified As Eligible Articles For Purposes of the U.S. Generalized System of Preferences. USITC Publication 2491 (March 1992).

Trade Between the United States and China, the Former Soviet Union, Central and Eastern Europe, the Batic Nations, and Other Selected Countries During 1991. USITC Publication 2503 (Aprif 1992).

Sulfanilic Acid from the Republic of Hungary and India. USITC Publication 2603 (February 1993).

Wang, Z.K, and L. Alan Winters. "The Trading Potential of Eastern Europe," Journal of Economic Integration (autumn 1992). pp. 113-36. 


\section{Appendix}

\section{Index of Relative Comparative Advantage: CSFR}

\begin{tabular}{|c|c|c|c|c|c|}
\hline Product & 1988 & 1989 & 1990 & 1991 & 1992 \\
\hline 00100 -Meat, poultry \& other edible animals & 3.692 & 3.938 & 3.597 & 1.072 & 0.031 \\
\hline 00110-Dairy products \& eggs & 3.215 & 3.239 & 3.616 & 4.585 & 4.418 \\
\hline 00120 m.mpits \& preparations & 0.046 & 0.013 & 0.047 & 3.189 & 1.130 \\
\hline $00130-$ Vegetables \& preparations & 0.034 & 0.000 & 0.000 & 0.017 & 0.495 \\
\hline 00160-Bakery \& confectionery products & 0.360 & 0.151 & 0.231 & 0.731 & 0.270 \\
\hline 00170-Tea, spices \& preparations & 0.000 & 0.000 & 1.184 & 0.000 & 0.000 \\
\hline 00180-Other (soft beverages, processed coffee, etc) & 3.019 & 0.028 & 0.000 & 0.000 & 0.116 \\
\hline o0190-Wine \& related products & 3.415 & 3.773 & 4.261 & 4.305 & 1.546 \\
\hline 00200-Feedstuff and foodgrains & 0.129 & 7.632 & 16.709 & 12.935 & 11.816 \\
\hline 01000 -Fish \& shelfish & 0.049 & 0.000 & 0.000 & 0.000 & 0.000 \\
\hline 01010-Alcoholic beverages, except wine & 0.010 & 0.944 & 0.077 & 0.038 & 0.126 \\
\hline 01020-Other nonagricultural foods \& food additives & 0.133 & 0.595 & 0.885 & 0.468 & 0.530 \\
\hline 10010-Fuet oil & 0.000 & 0.004 & 0.000 & 0.000 & 0.000 \\
\hline 10020 -Other petroleum products & 0.002 & 0.004 & 0.000 & 0.000 & 0.001 \\
\hline 10030-Liquified petroleum gases & 0.000 & 0.000 & 0.000 & 0.000 & 0.000 \\
\hline 10100 -Coal \& other fuels, except gas & 0.000 & 0.000 & 0.000 & 0.032 & 0.000 \\
\hline 10300-Nuclear fuel materials \& fuels & 0.000 & 0.000 & 0.000 & 0.005 & 0.000 \\
\hline 11000 -Pulpwood and woodpulp & 0.000 & 0.080 & 0.000 & 0.000 & 0.000 \\
\hline $11100-$ Newsprint & 0.038 & 2.309 & 0.000 & 0.000 & 0.000 \\
\hline$\$ 1110$-Waper \& paper products, n.e.s. & 0.080 & 0.000 & 0.000 & 0.017 & 0.041 \\
\hline$\{2000-$ Cotton, wool \& other natural fibers & 0.000 & 3.923 & 0.000 & 0.000 & 0.000 \\
\hline 12030-mides \& skins, \& fur skins-raw & 0.417 & 0.000 & 0.000 & 0.000 & 0.000 \\
\hline 12060-marming materials, including farm animals & 0.000 & 0.031 & 0.125 & 0.410 & 0.366 \\
\hline 12070 - Other (tobacco, waxes, nonfood oils) & 0.004 & 6.477 & 14.058 & 8.566 & 8.418 \\
\hline 12100 - Cotton cloth \& fabrics, thread \& cordage & 3.268 & 4.971 & 2.902 & 1.812 & 3.902 \\
\hline 12110-Wool, silk \& other vegetable fabric & 7.372 & 14.032 & 17.173 & 19.819 & 23.339 \\
\hline $12135-$ Synthetic cloth \& fabric, thread & 0.528 & 5.618 & 5.218 & 9.048 & 10.218 \\
\hline 12140 -Other materials (hair, synthetics, etc.) & 67.477 & 12.076 & 0.000 & 0.200 & 0.000 \\
\hline 12150-Finished textile industrial supplies & 11.145 & 3.257 & 1.468 & 1.555 & 0.776 \\
\hline 12160-Leather \& furs-unmanufactured & 0.000 & 0.012 & 0.341 & 0.000 & 0.932 \\
\hline 12320 -Other materials, except chemicals & 1.637 & 0.070 & 0.040 & 0.068 & 0.000 \\
\hline 12500 -Plastic materials & 0.100 & 0.278 & 0.276 & 0.091 & 0.090 \\
\hline 125 to-Fertilizers, pesticides, and insecticides & 0.007 & 0.000 & 0.023 & 0.000 & 0.000 \\
\hline 12530-Industrial inorganic chemicals & 0.863 & 3.117 & 0.736 & 1.282 & 2.610 \\
\hline 12540 -industrial organic chemicals & 0.732 & 0.075 & 0.114 & 0.439 & 0.500 \\
\hline 12550 -Other chemicals (coloring agents, print inks, paint) & 0.026 & 0.418 & 0.100 & 1.726 & 4.199 \\
\hline 13000 -Lumber \& wood in the rough & 0.074 & 0.428 & 0.040 & 0.000 & 0.005 \\
\hline 13010 -.mplyood \& veneers & 0.000 & 0.000 & 0.015 & 0.000 & 0.000 \\
\hline 13020-Stone, sand, cement \& lime & 0.000 & 0.859 & 0.266 & 0.077 & 0.225 \\
\hline 13100-Glass-ptate, sheet, etc. (excluding automotive) & 5.740 & 5.540 & 6.474 & 2.646 & 8.581 \\
\hline 13110 -Other-finished (shingles, molding, etc.) & 1.676 & 0.280 & 0.302 & 0.140 & 0.089 \\
\hline $13120-$-Nontextile floor \& wall tiles and other covering & 0.000 & 0.338 & 0.045 & 0.000 & 0.052 \\
\hline 14000-Steelmaking \& ferroalloying material & 0.000 & 0.000 & 0.000 & 1.882 & 1.462 \\
\hline $14100-$ - Iron \& steel mill products-semifinished & 6.779 & 5.233 & 1.603 & 1.936 & 1.828 \\
\hline 14200-Bauxite \& aluminum & 0.000 & 0.000 & 0.000 & 0.000 & 0.000 \\
\hline
\end{tabular}




\begin{tabular}{|c|c|c|c|c|c|}
\hline Product & 1988 & 1989 & 1990 & 1991 & 1992 \\
\hline 14220-Copper & 0.000 & 0.000 & 0.000 & 0.000 & 0.013 \\
\hline 14240-Nickel & 0.736 & 0.000 & 0.000 & 0.000 & 0.010 \\
\hline 14280-Other precious metals & 0.000 & 0.000 & 0.000 & 0.000 & 0.000 \\
\hline 14290-Miscellaneous nonferrous & 0.050 & 0.000 & 0.000 & 0.550 & 0.346 \\
\hline 15000-Iron and steel products, except advanced & 1.911 & 2.256 & 0.664 & 3.417 & 1.730 \\
\hline 15100-Iron and steel manufactured, advanced & 0.044 & 0.008 & 0.014 & 0.285 & 0.834 \\
\hline 15200-Finished metal shapes, except steel & 0.006 & 0.004 & 0.042 & 0.042 & 0.098 \\
\hline 16040-Sulfur \& nonmetallic minerals & 5.051 & 0.037 & 0.000 & 0.000 & 0.016 \\
\hline 16050-Other (synthetic rubber, wood, cork, gums, etc.) & 0.000 & 0.000 & 0.000 & 0.000 & 0.120 \\
\hline 16120-Other (boxes, belting, glass, abrasives, etc.) & 0.370 & 0.160 & 0.355 & 0.484 & 0.735 \\
\hline 20000 -Generators, transformers \& accessories & 0.977 & 0.019 & 0.000 & 0.074 & 0.103 \\
\hline 20005-Electric apparatus \& parts, n.e.c & 0.008 & 0.049 & 0.002 & 0.065 & 0.061 \\
\hline 21000-Drilling \& oil field equipment & 10.966 & 10.488 & 5.828 & 5.448 & 0.000 \\
\hline 21010-Specialized mining \& oil processing equipment & 0.000 & 0.000 & 0.000 & 0.434 & 1.833 \\
\hline 21030-Excavating, paving \& construction & 0.040 & 0.016 & 0.000 & 0.350 & 0.863 \\
\hline 21040-Nonfarm tractors \& parts & 1.440 & 4,487 & 3.207 & 0.434 & 0.797 \\
\hline 21100-Industrial engines, pumps, compressors \& generators & 0.000 & 0.002 & 0.081 & 0.115 & 0.093 \\
\hline 21110-Food \& tobacco processing machinery & 0.000 & 0.000 & 0.000 & 0.118 & 0.483 \\
\hline 21120-Machine tooss, metal working & 3.611 & 2,725 & 3.775 & 2.599 & 4.361 \\
\hline 21130-Industrial textiles, sewing, \& leather working machinery & 2.023 & 3.872 & 3.845 & 6.689 & 6.092 \\
\hline 21140-Woodworking, glass working, and piastic machinery & 0.014 & 0.004 & 1.492 & 1.125 & 0.308 \\
\hline 21150-Pulp \& paper machinery & 2.249 & 3.725 & 5.315 & 1.998 & 2.347 \\
\hline 21160-Measuring, testing \& control instruments & 0.000 & 0.036 & 0.343 & 0.197 & 0.363 \\
\hline 21170-Materials handling equipment & 0.000 & 0.006 & 0.437 & 1,331 & 0.838 \\
\hline 21180 - Other industrial machinery & 0.158 & 0.454 & 1.461 & 4.629 & 5.436 \\
\hline 21190 - Photo \& other service industry machinery & 0.076 & 0.138 & 0.019 & 0.221 & 0.179 \\
\hline $21200-$ Agricultural machinery and equipment & 13.782 & 14.761 & 22.738 & 11.487 & 9.580 \\
\hline 21300 -Computers & 0.000 & 0.000 & 0.000 & 0.004 & 0.006 \\
\hline 21301-Computer accessories, peripherals & 0.001 & 0.105 & 0.025 & 0.003 & 0.062 \\
\hline $21320-$ Semiconductors & 0.000 & 0.000 & 0.000 & 0.014 & 0.009 \\
\hline 21400-Telecommunications equipment & 0.033 & 0.777 & 0.318 & 0.698 & 0.697 \\
\hline 21500-Business machinery \& equipment, except computers & 0.283 & 0.121 & 0.183 & 0.070 & 0.050 \\
\hline 21600-Laboratory, testing \& control instruments & 0.000 & 0.000 & 0.165 & 0.079 & 0.335 \\
\hline 21610-Other scientific, medical \& hospital equipment & 0.000 & 0.000 & 0.045 & 0.016 & 0.085 \\
\hline 22000 - Civilian aircraft, complete - all & 0.000 & 0.000 & 0.127 & 0.023 & 0.086 \\
\hline 22010-Parts for civilian aircraft & 0.002 & 0.006 & 0.000 & 0.070 & 0.161 \\
\hline 22020-Engines for civilian aircraft & 0.000 & 0.000 & 0.000 & 0.037 & 0.007 \\
\hline 22220 - Marine engines \& parts & 0.000 & 0.000 & 0.000 & 0.000 & 0.000 \\
\hline 30000-Complete \& assembled-new \& used & 0.001 & 0.000 & 0.000 & 0.000 & 0.000 \\
\hline 30100-Complete \& assembled & 0.004 & 0.478 & 0.000 & 0.000 & 0.016 \\
\hline 30200-Engines \& engine parts & 0.000 & 0.008 & 0.020 & 0.085 & 0.114 \\
\hline 30220-Automotive tires \& tubes & 10.637 & 9.019 & 12.498 & 13.744 & 9.249 \\
\hline 30230-Other parts \& accessories & 0.000 & 0.023 & 0.005 & 0.011 & 0.049 \\
\hline 40000-Apparel \& household goods-cotton & 0.689 & 0.398 & 0.398 & 0.709 & 1.023 \\
\hline 40010-Apparel \& household goods-wool & 20.882 & 13.846 & 14.072 & 20.096 & 10.616 \\
\hline 40020-Apparel \& household goods-other textiles & 0.042 & 0.542 & 0.436 & 0.894 & 0.974 \\
\hline 40030-Nontextile apparel \& household goods & 0.804 & 1.142 & 0.820 & 0.418 & 0.427 \\
\hline 40040-Footwear of leather, rubber, or other materials & 4.939 & 8.644 & 8.741 & 5.845 & 4.306 \\
\hline 40050-Sporting \& camping apparel and footwear \& gear & 9.108 & 0.942 & 0.392 & 2.958 & 2.179 \\
\hline 40100-Medicinal, dental \& pharmaceutical preparations & 2.254 & 0.116 & 0.249 & 0.369 & 1.367 \\
\hline
\end{tabular}




\begin{tabular}{|c|c|c|c|c|c|}
\hline Product & 1988 & 1989 & 1990 & 1991 & 1992 \\
\hline 40110-Books, magazines \& other printed material & 3.030 & 5.387 & 3.712 & 1.521 & 3.906 \\
\hline 40120-Toiletries \& cosmetics & 0.000 & 0.000 & 2.034 & 0.000 & 0.367 \\
\hline 40140 -Other products (notions, writing \& art supplies) & 1.579 & 1.194 & 1.538 & 1.601 & 1.598 \\
\hline 41000 mifurniture, household items, baskets & 1.898 & 2.914 & 3.516 & 3.304 & 2.699 \\
\hline $41010-$ Glassware and potcelain & 19.451 & 19.780 & 20.002 & 13.120 & 16.421 \\
\hline 41020-Cookware, chinaware, cuttery, house \& garden wares & 0.402 & 0.210 & 0.419 & 1.202 & 0.719 \\
\hline $41030-$ Household \& kitchen appliances & 0.004 & 0.000 & 0.000 & 0.009 & 0.007 \\
\hline 41040-Rugs \& other textile floor covering & 0.108 & 0.060 & 0.417 & 1.404 & 0.743 \\
\hline 41050-Other (clocks, portable typewriters, other goods) & 0.236 & 1.614 & 1.064 & 0.751 & 1.020 \\
\hline 41100-Motorcycles \& parts & 2.011 & 1.968 & 1.052 & 2.383 & 1.825 \\
\hline 41110 -Pleasure boats \& motors & 0.000 & 0.000 & 0.064 & 0.011 & 0.000 \\
\hline 41120-Toys, shooting \& sporting goods \& bicycles & 1.734 & 0.499 & 0.535 & 0.676 & 1.337 \\
\hline A1130-Photo \& optical equipment & 0.005 & 0.000 & 0.000 & 0.026 & 0.013 \\
\hline 41140-Musical instruments \& other recreational equipment & 2.628 & 7.830 & 9.132 & 14.905 & 12.279 \\
\hline 41210-Radios, phonographs, tape decks \& other stereo & 0.000 & 0.000 & 0.000 & 0.000 & 0.000 \\
\hline 41220-Records, tapes \& disks & 0.580 & $2 . \dagger 22$ & 6.494 & 2.147 & 1.460 \\
\hline 41300-Numismatic coins & 0.096 & 0.273 & 0.293 & 0.186 & 0.033 \\
\hline 41310-Jewelry (watches, rings, etc.) & 1.239 & 0.306 & 0.163 & 0.251 & 0.685 \\
\hline 41320-Artwork, antiques, stamps and other collectibles & 1.527 & 1.866 & 2.124 & 1.877 & 3.018 \\
\hline 42000-Nursery stocks, cut flowers, Christmas trees & 24.705 & 0.055 & 0.000 & 0.000 & 0.000 \\
\hline $42100-$ Gem diamonds-uncut or unset & 0.000 & 0.000 & 0.000 & 0.011 & 0.000 \\
\hline 42110 -Other gem stones-precious, semiprecious, \& imitations & 18.437 & 28.459 & 29.001 & 26.076 & 28.718 \\
\hline 50000 -Military aircraft \& parts & 0.000 & 0.000 & 0.000 & 0.072 & 0.223 \\
\hline 50010-Other miltary equipment & 0.000 & 1.168 & 2.261 & 2.980 & 3.917 \\
\hline 50020-U.S. goods retumed, \& reimports & 0.083 & 0.238 & 0.068 & 0.243 & 0.224 \\
\hline 50030 -Minimum value shipments & 3.031 & 2.657 & 2.932 & 2.595 & 2.258 \\
\hline 50040 -Other (movies, miscellaneous imports \& special transactions) & $0.40 t$ & 2.284 & 1.511 & 5.017 & 7.577 \\
\hline
\end{tabular}

\section{Index of Relative Comparative Advantage: Hungary}

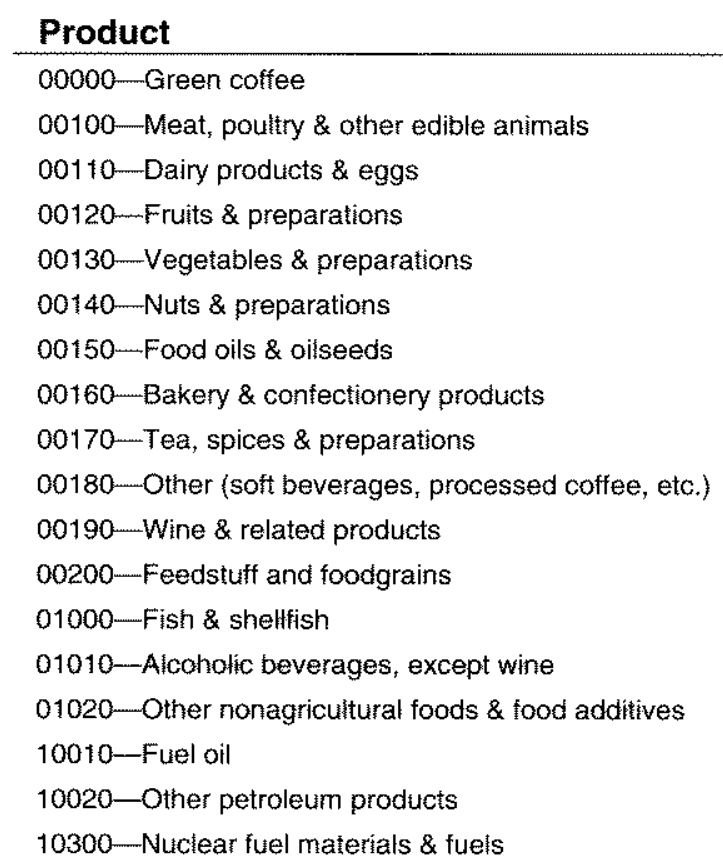

\begin{tabular}{rrrrr}
1988 & 1989 & 1990 & 1991 & 1992 \\
\hline 0.000 & 0.097 & 0.000 & 0.000 & 0.000 \\
14.591 & 9.405 & 12.703 & 13.159 & 8.179 \\
11.418 & 19.675 & 14.758 & 19.731 & 21.707 \\
6.771 & 10.356 & 10.951 & 12.691 & 8.122 \\
4.861 & 9.420 & 4.692 & 3.826 & 2.697 \\
0.096 & 0.069 & 0.000 & 0.000 & 0.050 \\
0.057 & 0.000 & 0.418 & 0.000 & 0.614 \\
0.144 & 0.814 & 1.713 & 1.816 & 1.361 \\
4.940 & 6.259 & 5.211 & 5.039 & 3.535 \\
2.051 & 2.679 & 1.673 & 1.157 & 0.271 \\
1.393 & 1.778 & 1.993 & 2.197 & 2.516 \\
0.819 & 1.749 & 1.310 & 1.441 & 5.223 \\
0.000 & 0.001 & 0.026 & 0.000 & 0.000 \\
0.016 & 0.044 & 0.066 & 0.104 & 0.150 \\
2.170 & 1.416 & 1.667 & 1.439 & 1.268 \\
0.000 & 0.000 & 0.000 & 0.001 & 0.000 \\
0.179 & 0.303 & 0.177 & 0.190 & 0.234 \\
0.000 & 0.000 & 0.056 & 0.069 & 0.014
\end{tabular}


Product

1 too0-mulpwood and woodpulp

$11110-$ Paper \& paper products, n.e.s.

12000 -Cotton, wool \& other natural fibers

12030 - Hides \& skins, \& fur skins-raw

12060 - Farming materials, including farm animals

12070 mother (tobacco, waxes, nonfood oils)

12100 Cotton cloth \& fabrics, thread \& cordage

12110 Wool, silk \& other vegetable fabric

12135 - Synthetic cloth \& fabric, thread \& cordage

12140 Other materials (hair, synthetics, etc.)

12150 - Finished textile industriak supplies

12160 - Leather \& furs-unmanufactured

12320 -Other materials, except chemicals

12500 -Plastic materials

12510 -Fertilizers, pesticides, and insecticides

12530 -Industriał inorganic chemicals

12540 - Industrial organic chemicals

12550 - Other chemicals (coloring agents, print inks, paint)

13000 -Lumber $\&$ wood in the rough

13010 -plywood \& veneers

13020 -Stone, sand, cement \& lime

13100 -Glass-plate, sheet, etc. (excluding automotive)

13110 -Other-finished (shingles, molding, wallboard, etc.)

13120 -Nontextile foor \& wall tifes and other covering

$\$ 4000$-Steelmaking \& ferroalloying materials

14100 -Iron \& steel mill products-semifinished

14200 -Bauxite \& aluminum

14220 -Copper

14240-Nickel

14270-Nonmonetary gold

$\$ 4280$-Other precious metals

14290-Miscellaneous nonferrous

15000 - Iron and steel products, except advanced manufacturers

15100 -tron and steel manufacturers, advanced

15200 -Finished metal shapes, except steel

16040 -Sulfur \& nonmetallic minerals

16050 -Other (synthetic rubber, wood, cork, gums, resins, etc.)

16110-Audio \& visual tapes \& other media

16120 - Other (boxes, belting, glass, abrasives, etc.)

20000 Generators, transformers \& accessories

20005 - Electric apparatus \& parts, n.e.c

21000 milling \& ol field equipment \& platforms

21010 - Specialized mining \& oil processing equipment

21030-..mexcavating, paving \& consiruction machinery

21040-Nonfarm tractors \& parts

21100 -Industrial engines, pumps, compressors \& generators

21110 Food \& tobacco processing machinery

21120 - Machine tools, melal working, molding \& rolling

21130 -industrial textiles, sewing, \& leather working machinery

21140 -Woodworking, glass working, \& plastic \& rubber machinery
1988

1989

1990

1991

1992

0.004

0.000

0.021

0.027

$1.253 \quad 2.597$

$0.159 \quad 0.067$

$\$ 1.475 \quad 25.183$

$1.093 \quad 2.792$

9.846

6.299

6.093

2.417

5.273

0.143

0.293

0.049

0.000

2.253

0.476

3.683

0.000

0.000

0.095

0.033

0.000

0.000

0.046

1.917

0.154

0.000

0.000

0.032

0.000

0.063

0.076

0.148

6.805

0.549

0.022

0.000

1.040

0.003

0.449

0.467

0.000

0.202

0.639

0.054

0.089

0.183

0.031

0.029

0.000

0.004

0.465

0.099

5.298

3.089

4.046

4.086

2.439

5.336

3.206

0.611

0.740

2.453

0.000

1.542

1.234

0.653

0.000

0.009

0.000

0.000

0.002

0.012

0.003

2.083

0.000

0.000

0.145

0.034

0.000

0.069

0.003

0.017

6.608

0.203

0.065

0.001

3.016

0.180

0.640

0.787

0.000

0.000

0.000

0.000

0.014

0.191

0.340

0.174

0.325

0.079

0.531

1.046

0.000

0.010

0.012

0.119

$0.000 \quad 0.000$

$0.000 \quad 0.010$

$1.331 \quad 1.180$

$0.026 \quad 0.000$

$0.403 \quad 3.101$

$5.543 \quad 3.044$

$1.343 \quad 1.325$

$4.559 \quad 3.813$

$1.953 \quad 1.364$

$0.758 \quad 0.047$

$1.927 \quad 2.001$

$2.222 \quad 0.000$

$1.006 \quad 1.140$

$1.372 \quad 1.371$

$0.789 \quad 1.679$

$1.481 \quad 1.621$

$0.750 \quad 1.171$

$0.575 \quad 0.203$

$0.001 \quad 0.001$

$0.000 \quad 0.000$

$0.000 \quad 0.000$

$\begin{array}{ll}0.128 & 0.033\end{array}$

$0.004 \quad 0.009$

$0.088 \quad 0.000$

$0.000 \quad 0.000$

$1.162 \quad 0.988$

$0.086 \quad 0.000$

$0.000 \quad 0.040$

$0.000 \quad 0.000$

$0.007 \quad 0.000$

$0.000 \quad 0.000$

$0.645 \quad 1.095$

$0.003 \quad 0.138$

$0.026 \quad 0.055$

$5.552 \quad 9.806$

$0.091 \quad 0.000$

$0.136 \quad 0.066$

$0.000 \quad 0.000$

$2.535 \quad 1.666$

$0.522 \quad 1.268$

$0.897 \quad 1.295$

$0.000 \quad 0.000$

$0.000 \quad 0.024$

1. $150 \quad 0.113$

$0.025 \quad 3.454$

$0.610 \quad 0.635$

$0.009 \quad 0.006$

$0.949 \quad 0.292$

$0.016 \quad 0.176$

$0.152 \quad 3.631$ 


\begin{tabular}{|c|c|c|c|c|c|}
\hline Product & 1988 & 1989 & 1990 & 1991 & 1992 \\
\hline 21150-Pulp \& paper machinery & 0.002 & 0.015 & 0.010 & 0.600 & 0.371 \\
\hline 21160-Measuring, testing \& control instruments & 0.254 & 0.314 & 0.212 & 0.193 & 0.671 \\
\hline 21170-Materiaks handing equipment & 0.138 & 0.332 & 0.289 & 0.514 & 0.322 \\
\hline 21180 -Other industrial machinery & 1.301 & 1.588 & 1.846 & 0.908 & 0.963 \\
\hline 21190-Photo \& other service industry machinery & 0.225 & 0.290 & 0.176 & $0 . \uparrow 44$ & 0.122 \\
\hline 21200-Agricultural machinery and equipment & 3.852 & 7.856 & 7.170 & 8.139 & 10.255 \\
\hline $21300-$ Computers & 0.000 & 0.001 & 0.003 & 0.002 & 0.001 \\
\hline 21301-Computer accessories, peripherals \& parts & 0.000 & 0.007 & 0.004 & 0.013 & 0.006 \\
\hline 21320 - Semiconductors & 0,007 & 0.001 & 0.009 & 0.003 & 0.030 \\
\hline 21400-Telecommunications equipment & 0.191 & 0.014 & 0.012 & 0.026 & 0.014 \\
\hline 21500-Business machinery \& equipment, except computers & 0.010 & 0.290 & 0.141 & 0.079 & 0.030 \\
\hline 21600-Laboratory, testing \& control instruments & 0.013 & 0.078 & 0.060 & 0.432 & 1.204 \\
\hline 21610-Other scientific, medical \& hospital equipment & 0.071 & 0.172 & 0.075 & 0.113 & 0.163 \\
\hline 22000-Civilian aircraft, complete - all & 0.009 & 0.003 & 0.009 & 0.004 & 0.011 \\
\hline 22010-Parts for civilian aircraft & 0.000 & 0.005 & 0.019 & 0.033 & 0.010 \\
\hline 22020 -Engines for civilian aircraft & 0.000 & 0.000 & 0.000 & 0.000 & 0.096 \\
\hline 22100-Failway transportation equipment & 0.086 & 0.000 & 0.174 & 0.512 & 0.010 \\
\hline 22210-Other commercial vessels, new and used & 0.000 & 0.000 & 0.000 & 0.698 & 0.000 \\
\hline 22220-Marine engines \& parts & 0.000 & 0.000 & 0.000 & 0.000 & 0.011 \\
\hline $30100-T r u c k s$, buses, \& special purpose vehictes & 0.000 & 0.005 & 0.000 & 0.095 & 0.001 \\
\hline 30110-Bodies \& chassis for trucks \& buses & 0.001 & 2.774 & 15.454 & 29.076 & 9.517 \\
\hline 30200-Engines \& engine parts & 0.026 & 0.002 & 0.004 & 0.001 & 0.001 \\
\hline 30220-Automotive lires \& tubes & 5.801 & 5.468 & 4.798 & 1.667 & 0.643 \\
\hline 30230-Other parts \& accessories & 2.261 & 2.303 & 2.417 & 2.601 & 2.921 \\
\hline 40000-Apparel \& household goods-cotton & 1.245 & 1.688 & 1.715 & 1.646 & 1.972 \\
\hline 40010-Apparel \& household goods-wool & 17.527 & 18.727 & 14.530 & 13.901 & 21.349 \\
\hline 40020-Apparel \& household goods-other textiles & 2.414 & 2.043 & 1.512 & 1.472 & 1.920 \\
\hline 40030-Nontextile apparel \& household goods & 1.054 & 1.365 & 1.937 & 0.293 & 0.333 \\
\hline 40040 -Footwear of leather, rubber, or other materials & 4.334 & 2.658 & 4.401 & 3.076 & 2.342 \\
\hline 40050-Sporting \& camping apparel, footwear \& gear & 0.467 & 0.364 & 0.448 & 0.614 & 0.516 \\
\hline 40100-Medicinal, dental \& pharmaceutical preparations & 5.698 & 5.677 & 6.617 & 4.566 & 3.644 \\
\hline 40110-Books, magazines \& other printed material & 0.586 & 0.458 & 0.303 & 0.741 & 0.153 \\
\hline 40120 -Toiletries \& cosmetics & 0.059 & 0.039 & 0.016 & 0.172 & 0.060 \\
\hline 40140 -Other products (notions, writing \& art supplies) & 0.071 & 0.583 & 0.375 & 0.323 & 0.258 \\
\hline 41000 -Furniture, household items, baskets & 2.028 & 2.181 & 1.558 & 1.816 & 0.929 \\
\hline 41010 -Glassware and porcelain & 4.854 & 6.253 & 6.242 & 7.284 & 9.624 \\
\hline 41020 -Cookware, chinaware, cutlery, \& other household goods & 0.919 & 1.953 & 1.018 & 1.209 & 1.365 \\
\hline 41030-Household \& kitchen appliances & 0.011 & 0.000 & 0.006 & 0.028 & 0.005 \\
\hline 41040-Rugs \& other textile floor covering & 0.652 & 0.557 & 0.914 & 0.709 & 0.704 \\
\hline 41050-Other (clocks, portable typewriters, other household goods) & 6.246 & 2.651 & 2.073 & 2.936 & 1.817 \\
\hline 41100 -Motorcycles \& parts & 0.000 & 0.054 & 0.000 & 0.000 & 0.000 \\
\hline 41110 meleasure boats \& motors & 0.164 & 0.588 & 0.174 & 0.007 & 0.123 \\
\hline 41120 -Toys, shooting \& sporting goods, \& bicycles & 0.100 & 0.086 & 0.137 & 0.965 & 1.794 \\
\hline 41130 m-Photo \& optical eqquipment & 0.000 & 0.253 & 0.215 & 0.159 & 0.149 \\
\hline $41140-$ Musical instruments \& other recreational equipment & 0.102 & 0.318 & 0.315 & 0.300 & 0.352 \\
\hline 41200 m-Television receivers, vars \& other video equipment & 0.000 & 0.000 & 0.000 & 0.000 & 0.000 \\
\hline 41210-Radios, phonographs, tape decks \& other stereo & 0.000 & 0.000 & 0.001 & 0.003 & 0.000 \\
\hline 41220 -mecords, tapes \& disks & 2.405 & 1.617 & 2.066 & 1.810 & 1.391 \\
\hline 4t300-Numismatic coins & 0.059 & 0.078 & 6.805 & 0.668 & 0.223 \\
\hline 41310-Jewelry (watches, rings, etc) & 0.108 & 0.070 & 0.048 & 0.007 & 0.000 \\
\hline
\end{tabular}




\begin{tabular}{|c|c|c|c|c|c|}
\hline Product & 1988 & 1989 & 1990 & 1991 & 1992 \\
\hline 41320-Artwork, antiques, stamps and other collectibles & 0.664 & 0.695 & 1.063 & 4.373 & 1.429 \\
\hline 42000-Nursery stocks, cut flowers, Christmas trees & 0.000 & 0.003 & 0.055 & 0.205 & 0.246 \\
\hline 42100 -Gem diamonds-uncut or unset & 0.017 & 0.000 & 0.000 & 0.000 & 0.000 \\
\hline 42110 - Other gem stones-precious, semiprecious \& imitation & 0.000 & 0.016 & 0.004 & 0.000 & 0.000 \\
\hline 50000 -Military aircraft \& parts & 0.000 & 0.000 & 0.000 & 0.000 & 0.008 \\
\hline 50010-Other military equipment & 3.655 & 3.570 & 2.698 & 2.423 & 4.116 \\
\hline 50020 - U.S. goods returned, \& reimports & 0.106 & 0.090 & 0.070 & 0.224 & 0.129 \\
\hline 50030-Minimum value shipments & 0.511 & 0.364 & 0.380 & 0.401 & 0.378 \\
\hline 50040-Other (movies, miscellaneous imports \& special transactions) & 0.603 & 0.577 & 3.002 & 0.050 & 1.433 \\
\hline
\end{tabular}

\section{Index of Relative Comparative Advantage: Poland}

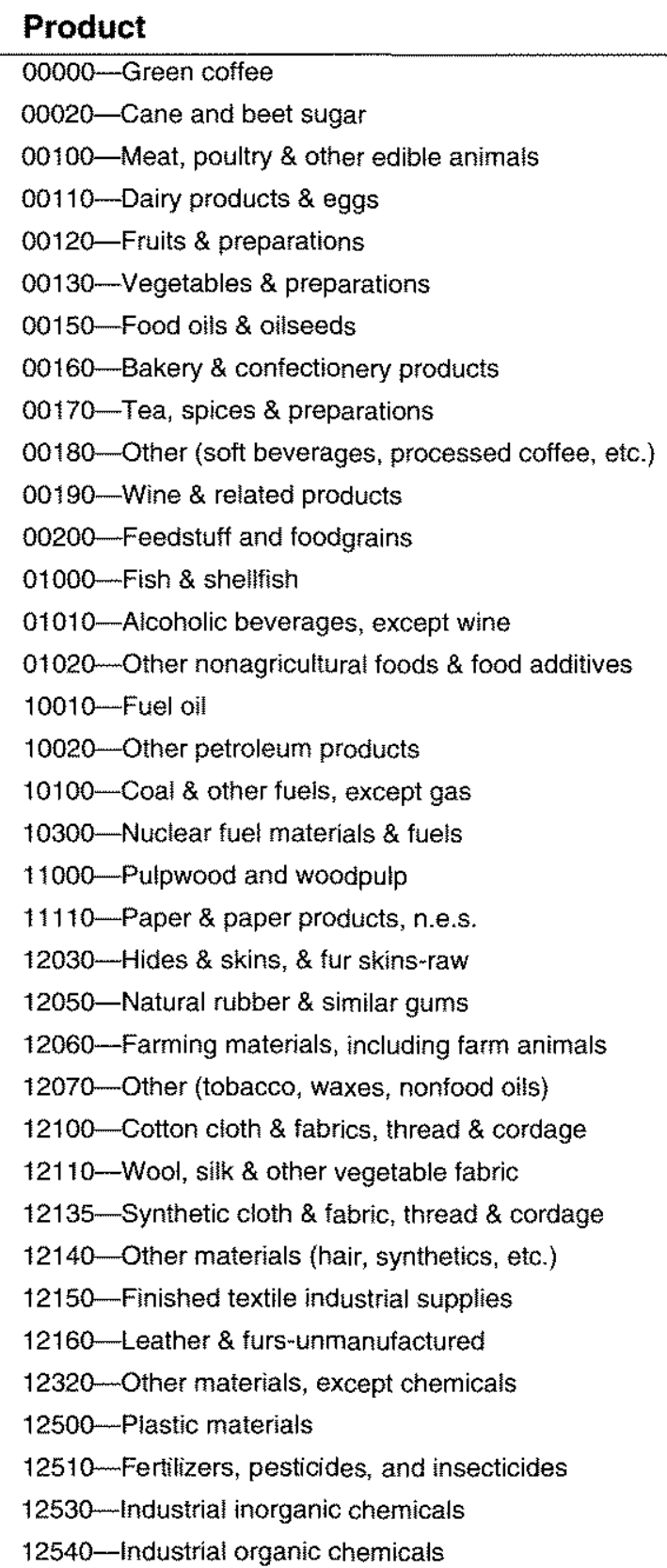

\begin{tabular}{rrrrr}
1988 & 1989 & 1990 & 1991 & 1992 \\
\hline 0.000 & 0.025 & 0.000 & 0.000 & 0.000 \\
0.000 & 0.072 & 0.000 & 0.000 & 0.000 \\
38.943 & 37.600 & 25.330 & 11.456 & 8.119 \\
6.980 & 13.598 & 7.710 & 11.218 & 21.245 \\
1.227 & 2.234 & 2.184 & 4.453 & 3.546 \\
0.803 & 1.038 & 1.214 & 1.788 & 1.298 \\
0.490 & 2.364 & 18.895 & 0.677 & 0.548 \\
1.024 & 1.522 & 1.335 & 2.500 & 3.081 \\
0.941 & 0.104 & 0.509 & 0.014 & 0.192 \\
0.905 & 0.957 & 1.090 & 0.570 & 2.039 \\
0.096 & 0.122 & 0.074 & 0.193 & 0.296 \\
7.577 & 0.153 & 0.024 & 4.586 & 4.428 \\
2.261 & 2.057 & 4.079 & 3.731 & 1.579 \\
0.151 & 0.263 & 1.560 & 1.573 & 0.623 \\
0.612 & 0.000 & 0.000 & 0.000 & 0.000 \\
0.000 & 0.000 & 0.000 & 0.000 & 0.408 \\
0.000 & 0.000 & 0.000 & 0.000 & 0.000 \\
0.000 & 36.870 & 0.000 & 0.000 & 0.139 \\
0.000 & 0.000 & 0.000 & 0.023 & 0.000 \\
0.000 & 0.000 & 0.000 & 0.000 & 0.000 \\
0.002 & 0.047 & 0.002 & 0.000 & 0.001 \\
0.566 & 0.795 & 0.593 & 1.845 & 2.689 \\
0.000 & 0.000 & 0.000 & 0.000 & 0.000 \\
9.954 & 2.174 & 2.867 & 1.913 & 2.326 \\
14.229 & 8.507 & 9.420 & 10.847 & 14.617 \\
2.222 & 0.634 & 1.167 & 1.794 & 0.672 \\
12.146 & 15.070 & 19.067 & 27.927 & 34.972 \\
1.011 & 1.782 & 2.071 & 2.919 & 2.880 \\
44.130 & 0.559 & 0.000 & 0.000 & 0.000 \\
0.001 & 0.676 & 0.051 & 0.010 & 0.000 \\
0.000 & 0.094 & 0.324 & 0.092 & 0.104 \\
0.028 & 2.298 & 0.000 & 0.002 & 0.016 \\
0.016 & 0.016 & 0.034 & 0.015 & 0.148 \\
0.002 & 0.131 & 0.000 & 1.959 & 2.332 \\
0.624 & 0.470 & 1.738 & 2.921 & 0.974 \\
0.445 & 0.731 & 0.263 & 0.513 & 0.250 \\
& & & &
\end{tabular}


Product

12550 - Other chemicals (coloring agents, print inks, paint)

13000 - Lumber \& wood in the rough

13010 . Plywood \& veneers

13020 - Stone, sand, cement \& lime

13100 - Glass-plate, sheet, etc. (excluding automotive)

13110 -Other-finished (shingles, molding, wallboard, eic.)

13120 Nontextile floor \& wall tiles and other covering

14000 - Steelmaking \& ferroalloying materials

14100 - Iron \& steel mill products-semifinished

14200 -Bauxite \& aluminum

14220-Copper

14240 -Nickel

14260 -Zinc

14270 - Nonmonetary gold

14280 -Other precious metals

14290-Miscellaneous nonferrous

15000 -Iron and steel products, except advanced manufacturers

15100-Iron and steel manufacturers, advanced

15200 -Finished metal shapes, except steel

16040 -Sulfur \& nonmetallic minerals

16050 -Other (synthetic rubber, wood, cork, gums, resins, etc.)

16110 -Audio \& visual tapes \& other media

16120 -Other (boxes, beiting, glass, abrasives, etc.)

20000 -Generators, transformers \& accessories

20005-Electric apparatus \& parts, n.e.c

21000 -Drilling \& oil field equipment \& platforms

21010-Specialized mining \& oil processing equipment

21030-Excavating, paving \& construction machinery

21040-Nonfarm tractors \& parts

21100-Industralal engines, pumps, compressors \& generators

21110 -Food \& tobacco processing machinery

21120-Machine tools, metal working, molding \& roling

21130-industrial textiles, sewing, \& leather working machinery

21140 -Woodworking, glass working, \& plastic \& rubber machinery

21150 -Pulp \& paper machinery

$21160-$ Measuring, testing \& control instruments

$21170-$ Materials handling equipment

21180 -Other industrial machinery

21190-Photo \& other service industry machinery

21200-Agriculural machinery and equipment

21300 - Computers

$21301-$-Computer accessories, peripherals \& parts

21320 -Semiconductors

21400--Telecommunications equipment

21500-Business machines \& equipment, except computers

21600-Laboratory, testing \& control instruments

$21610-O t h e r$ scientific, medical \& hospital equipment

22000-Civilian aircraft, complete - all

$22010-P a r t s$ fo: civilian aircraft

22020-Engines for civilian aircraft
1988

1989

1990

$+.319$

2.636

1.089

0.000

0.000

0.000

1991

1992

0.734

0.000

0.090

0.000

0.000

0.000

0.084

0.000

1.746

1.413

$0.000 \quad 0.002$

0.387

0.000

0.194

0.000

0.000

3.339

3.309

2.773

$0.151 \quad 0.090$

$6.709 \quad 13.997$

0.550

0.000

0.088

0.000

0.637

6.233

0.017

1.277

0.000

0.000

0.000

0.000

0.000

0.000

0.099

0.000

0.006

3.122

2.625

2.380

1.122

1.831

1.563

4.467

6.841

0.026

0.164

0.084

0.054

0.010

0.549

0.020

0.120

0.182

0.527

0.433

0.017

0.000

0.168

0.000

0.191

34.255

15.577

0.497

0.168

22.543

0.318

0.292

4.097

3.013

3.118

0.011

0.103

0.024

0.319

0.742

0.032

0.631

0.526

1.224

0.841

7.728

0.001

0.005

0.024

0.069

0.093

0.138

0.037

0.610

0.146

0.883
$4.231 \quad 4.385$

$0.000 \quad 0.000$

$0.741 \quad 3.899$

0.0210 .000

$1.788 \quad 0.931$

$0.000 \quad 0.005$

$0.000 \quad 0.000$

$0.000 \quad 0.580$

$4.461 \quad 1.915$

$0.178 \quad 0.000$

$0.000 \quad 0.018$

$0.000 \quad 0.000$

$0.020 \quad 1.756$

$0.030 \quad 0.000$

$0.002 \quad 0.000$

$0.187 \quad 0.000$

$2.249 \quad 1.404$

$2.255 \quad 1.311$

$8.239 \quad 9.644$

$0.004 \quad 0.018$

$0.328 \quad 0.163$

$0.000 \quad 0.000$

$0.401 \quad 0.199$

$1.216 \quad 0.443$

$0.544 \quad 0.892$

$0.057 \quad 0.202$

$0.219 \quad 0.291$

$0.078 \quad 0.520$

$27.693 \quad 12.064$

$0.490 \quad 0.773$

$0.400 \quad 1.063$

$4.574 \quad 4.903$

$0.074 \quad 0.000$

$0.710 \quad 0.570$

$0.056 \quad 0.148$

$0.686 \quad 0.632$

$0.674 \quad 0.140$

$1.311 \quad 2.106$

$0.709 \quad 0.739$

$7.220 \quad 10.719$

$0.013 \quad 0.000$

$0.018 \quad 0.011$

$0.050 \quad 0.043$

$0.028 \quad 0.010$

$0.189 \quad 0.076$

$0.120 \quad 0.342$

$0.083 \quad 0.226$

$0.362 \quad 0.210$

$0.223 \quad 0.008$

$0.665 \quad 0.583$ 


\begin{tabular}{|c|c|c|c|c|c|}
\hline Product & 1988 & 1989 & 1990 & 1991 & 1992 \\
\hline 22100 -Railway transportation equipment & 0.000 & 0.107 & 0.753 & 2.995 & 4.603 \\
\hline 22210-Other commercial vesseis, new and used & 0.000 & 0.000 & 0.198 & 0.000 & 0.000 \\
\hline 22220 -Marine engines \& parts & 0.000 & 0.007 & 0.000 & 0.021 & 0.000 \\
\hline 30000 -Passenger cars complete $\&$ assembled (new and used) & 0.001 & 0.000 & 0.000 & 0.000 & 0.000 \\
\hline 30100 Trucks, buses, \& special purpose vehicles & 0.349 & 0.357 & 0.376 & 0.335 & 0.214 \\
\hline 30110 - Bodies \& chassis for trucks \& buses & 0.000 & 0.000 & 0.000 & 0.094 & 0.000 \\
\hline 30200-Engines \& engine parts & 0.014 & 0.159 & 0.233 & 0.177 & 0.212 \\
\hline 30220-Automotive tires \& tubes & 0.000 & 0.000 & 0.125 & 0.855 & 0.660 \\
\hline 30230 - Other parts \& accessories & 0.023 & 0.035 & 0.028 & 0.040 & 0.096 \\
\hline 40000-Apparel \& household goods-colton & 2.692 & 2.802 & 3.593 & 2.109 & 1.981 \\
\hline 40010 -Apparel \& household goods-wool & 7.677 & 7.618 & 7.535 & 8.635 & 14.474 \\
\hline 40020-Apparel \& household goods-other textiles & 1.284 & 0.952 & 1.330 & 1.527 & 1.384 \\
\hline 40030-Nontextile apparel \& household goods & 0.176 & 0.098 & 0.301 & 0.074 & 0.040 \\
\hline 40040-Footwear of leather, rubber, or other materials & 1.138 & 1.699 & 1.178 & 1.891 & 2.439 \\
\hline 40050-Sporting \& camping apparel, footwear \& gear & 0.571 & 0.253 & 0.151 & 0.187 & 0.456 \\
\hline 40100-Medicinal, dental \& pharmaceutical preparations & 1.728 & 1.006 & 0.293 & 0.485 & 0.435 \\
\hline 40110-Books, magazines \& other printed material & 0.122 & 0.118 & 0.150 & 0.059 & 0.174 \\
\hline 40120-Toiletries \& cosmetics & 0.055 & 0.025 & 0.032 & 0.012 & 0.046 \\
\hline 40140-Other products (notions, writing \& art supplies) & 0.010 & 0.014 & 0.069 & 0.094 & 0.078 \\
\hline 41000 -Furniture, household items, baskets & 2.617 & 2.883 & 3.681 & 3.452 & 2.989 \\
\hline 41010-Glassware and porcelain & 5.992 & 14.285 & 19.087 & 25.244 & 28.039 \\
\hline 41020-Cookware, chinaware, cutlery, \& other household goods & 0.745 & 0.489 & 0.720 & 0.437 & 0.330 \\
\hline 41030-Household \& kitchen appliances & 0.120 & 0.116 & 0.553 & 1.337 & 1.084 \\
\hline 41040 -Rugs \& other textile floor covering & 0.295 & 0.053 & 0.170 & 0.135 & 0.166 \\
\hline 41050-Other (clocks, portable typewriters, other household goods) & 2.462 & 1.848 & 2.991 & 3.058 & 2.453 \\
\hline $41100-$ Motorcycles \& parts & 0.000 & 0.002 & 0.000 & 0.000 & 0.071 \\
\hline 41110 -Pleasure boats \& motors & 0.048 & 0.076 & 0.297 & 0.000 & 0.009 \\
\hline 41120 -Toys, shooting \& sporting goods, \& bicycles & 0.448 & 0.488 & 0.507 & 0.316 & 0.385 \\
\hline 41130-m-Photo \& optical equipment & 0.000 & 0.044 & 0.052 & 0.043 & 0.052 \\
\hline 41140-Musical instruments \& other recreational equipment & 0.015 & 0.007 & 0.071 & 0.407 & 0.160 \\
\hline 41200 -Television receivers, vcrs \& other video equipment & 0.000 & 0.000 & 0.000 & 0.000 & 0.029 \\
\hline 41210 - Radios, phonographs, tape decks \& other stereo & 0.000 & 0.000 & 0.007 & 0.007 & 0.014 \\
\hline 41220-Records, tapes \& disks & 0.160 & 0.066 & 0.125 & 0.380 & 0.505 \\
\hline $41300-$ Numismatic coins & 6.560 & 1.878 & 0.112 & 0.807 & 0.975 \\
\hline 41310-Jeweiry (watches, rings, etc.) & 0.014 & 0.034 & 0.092 & 0.112 & 0.144 \\
\hline 41320-Artwork, antiques, stamps and other collectibles & 0.084 & 0.674 & 0.234 & 0.309 & 0.365 \\
\hline 42000-Nursery stocks, cut flowers, Christmas trees & 1.269 & 0.000 & 0.061 & 0.042 & 0.380 \\
\hline 42100 - Gem diamonds-uncut or unset & 0.000 & 0.000 & 0.024 & 0.000 & 0.000 \\
\hline 42110--Other gem stones-precious, semiprecious \& imitation & 0.050 & 0.022 & 0.044 & 0.103 & 0.191 \\
\hline 50000 -Military aircraft \& parts & 0.004 & 0.000 & 0.163 & 0.221 & 1.420 \\
\hline 50010-Other military equipment & 0.105 & 0.000 & 0.130 & 0.311 & 0.373 \\
\hline 50020-U.S. goods retumed, \& reimports & 0.422 & 0.462 & 0.332 & 0.412 & 0.515 \\
\hline 50030-Minimum value shipments & 0.727 & 0.567 & 0.535 & 0.535 & 0.728 \\
\hline 50040-Other (movies, miscellaneous imports \& special transe & 0.372 & 0.170 & 0.728 & 0.246 & 1.640 \\
\hline
\end{tabular}

